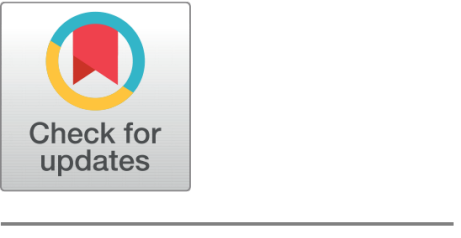

OPEN ACCESS

Received: 23.05.2021

Accepted: 28.06.2021

Published: 09.07.2021

Citation: A. Lim EJ (2021) Math Class Gamified! Effects on the

Mathematics Performance of COED

Students of Eastern Samar State

University, Philippines. Indian

Journal of Science and Technology

14(23): 1970-1974. https://doi.org/

10.17485/IJST/v14i23.902

* Corresponding author.

sluj_0918@yahoo.com

Funding: ESSU RDSO

Competing Interests: None

Copyright: (c) $2021 \mathrm{~A}$. Lim. This is an open access article distributed under the terms of the Creative Commons Attribution License, which permits unrestricted use, distribution, and reproduction in any medium, provided the original author and source are credited.

Published By Indian Society for Education and Environment (iSee)

ISSN

Print: 0974-6846

Electronic: 0974-5645

\section{Math Class Gamified! Effects on the Mathematics Performance of COED Students of Eastern Samar State University, Philippines}

\author{
Edgar Julius A. Lim ${ }^{1 *}$ \\ 1 Eastern Samar State University
}

\section{Abstract}

Objectives: The purpose of the study was to see what impacts using games had on teaching and evaluating students' math ability. Its goal was to determine the performance in the pretest and posttest of the students under study, and to discover if there is difference in the performance of the students under study in their pretest and posttest. Methods: This study utilized the one group pretest - posttest experimental design. It sought to find the difference in the performance of students who were exposed to a certain method in teaching mathematics. Findings: No significant difference was found between the pretest and posttest scores, and a very little mean difference was revealed, presenting that the null hypothesis was to be accepted, and showing that gamified classes are not always a better teaching strategy for teaching problem solving in mathematics. Novelty/Applications: Game integration or plays in classes are not assurance of learning effectiveness. The fun the learners have when integrating games are not enough to presume that learning is taking place. Results of this study tell us that games as a teaching approach would only be effective to some lessons in math.

Keywords: Gamified Class; Math Games; Math Class; Mathematics Performance; Experimental Research

\section{Introduction}

Via participation, games are thought to increase motivation. Glover describes a game as "a type of participatory, or interactive, entertainment," as opposed to passive activities like watching TV or reading. ${ }^{(1)}$ Since learning is a participatory activity, integrating game concepts into education can provide greater benefits than these other, passive practices. Gamification is integrating of game elements to non-game activities. ${ }^{(2)}$

According to the Utendorf August 13, 2013 article on IntrepidLearning.com, gamification is the process of motivating consumers, staff, and learners in non-gaming environments by using gaming techniques and mechanics. ${ }^{(3)}$ Learning is not turned into a game; rather, the features that entice players to engage in games (curiosity, collecting, discovery, and dominance, to name a few) are used to entice learners to participate. 
Gamification encourages people to learn by themselves which enhance results and processes. Learners may use gamification to learn on their own time and at their own speed. Learners appreciate the right to make mistakes when experimenting in a safe environment. Learners may feel anger, curiosity, amusement, and mystery. Each of which provides one's own link to the players. ${ }^{(4)}$

Iulian said that teachers must employ a variety of teaching approaches and different methods that enable student-participants to be active in their own learning, with high motivation and commitment, and one of these trends is the use of innovative approaches and strategies to incorporate active learning and gamification in training. ${ }^{(5)}$ Gamification is becoming more popular as a method of increasing student participation in the classroom. ${ }^{(2)}$

Gamification has recently become an influential instructional tool in K-12 curriculum, as well as in public and private colleges and universities. Gamification is a strategy for increasing information acquisition when involving learners in an immersive learning environment. It's also social, stimulating, and gives students a chance to try new things. ${ }^{(4)}$ Games and gamification are satisfying for the educational environment and the experiences in the learning process. The key modifications between gamebased learning and gamification indicate, first, that gamification doesn't require content to be adapted to suit the game story and, second, that gamification does not require content to be adapted fitting to the rules and story in the game-based learning. Gamification, on the other side of the story is accepted to change a learning activity into an instructive game by utilizing elements to inspire and have students engaged, while games are used to gain skills or expertise in game-related learning activities. ${ }^{(5)}$

Instructors who wanted to use gamification in the classroom wanted to take the influence of games the ability to attempt and fail and try again, the feeling of accomplishment when completing a challenging task and apply it to their teaching. After all, games are incredibly inspiring and engaging; they use a variety of strategies to motivate learners to participate with them, oftentimes, even without any monetary incentive, only for the fun of joining the game and the chance to win." They "reinforce not only information but also essential skills like problem-solving, teamwork, and communication," according to the writers. ${ }^{(6)}$

An effective gamification concept is a successful gamification definition is that it catches, preserves learners' interest, engages, and challenges them, and eventually teaching them. Gamification is still in its infancy, and researchers are still figuring out how and why it works, as well as what makes it successful. ${ }^{(5)}$

Despite this confusion, there are some advantages of using gamification in the instructional process, including a better learning environment by mixing "fun" and learning while enjoying the game, a successful gamification approach can better make participants engaged, and higher levels of participation will improve input and retention.

With all these, this study was conducted - to find how gamification will affect the performance of students in Mathematics.

\section{Objectives of the Study}

This experiment's goal was to determine the difference in the mathematics performance of students who were taught with gamified mathematics.

Specifically, it sought to find the following;

1. to determine the pretest performance of the students under study,

2. to determine the posttest performance of the students under study, and

3. to find the difference in the pretest and posttest performance of the students under study.

\section{METHODOLOGY}

\section{Research Design}

This experiment utilized the one group pretest - posttest experimental design. It tried to find the difference in the performance of students who were exposed to a certain method in teaching mathematics.

\section{Research Locale}

The study was conducted in the only state university in the province, Eastern Samar State University College of Education, Borongan Campus. It is located in the northern part of the City at Barangay Maypangdan, Philippines.

\section{Subjects of the Study}

In this study, the subjects were the third year BEED students who were enrolled during the Second Semester of School Year $2018-2019$. 


\section{Research Instrument}

The study adopted 20 - item test used from book The Art of Problem Solving ${ }^{(7)}$ and was administered as the pretest and posttest before and after the actual experimentation.

\section{Statistical Treatment of Data}

The mean was used to determine the mean mathematics performance of the subjects under study. $\mathrm{T}$ - test was utilized to find if there is difference in the pretest and posttest scores of the subjects who were exposed in the gamified math class as teaching approach.

\section{Data Gathering Procedure}

Pre Experimental Stage: The pretest was administered to the subjects before the actual experimentation begun.

Experimental Stage: The group of students under study was taught using the gamified math class, the teaching approach used in the study. Since the concept included in the study is Non-routine word problems, where problems given to the learners are games in itself. Some are physical games where the learners need to make themselves part of the game in solving the problem others use manipulative to find the answers, but mostly are mind games where most of the students analyze the situation, try to come up with a strategy of their own to come up with a solution and be able to solve the problem.

Post Experimental Stage: After the experimentation, the posttest was administered to every member of the group under study.

Data was evaluated and analyzed.

\section{RESULTS AND DISCUSSION}

Table 1 presents the mean of the pretest and posttest performance of the28-member group under study. The mean of the posttest performance at 2.29 with a standard deviation of 0.95 is higher than the pretest performance, 1.93 with a standard deviation of 0.88 . The posttest performance revealed a higher mean implying that learning took place.

The standard deviation of the pretest at 0.88 and posttest at 0.95 shows that scores obtained in both the pretest and posttest are not far from the their respective mean implying that scores obtained in both test are almost similar or close with each of the other scores.

Table 1. Pretest and Posttest Performance

\begin{tabular}{llll}
\hline & $\mathrm{N}$ & Mean & SD \\
\hline Pretest & 28 & 1.93 & 0.88 \\
Posttest & 28 & 2.29 & 0.95 \\
\hline
\end{tabular}

Table 2 shows the $t$-test result in the pretest and posttest performance of the 28 subjects in the group under study. With the mean pretest and posttest performance of 0.88 and 0.95 respectively, a very minimal mean difference of 0.36 is revealed. From these results, with a $p$ value of 0.33 , which is greater than 0.05 level of significance, there was no significant difference. Hence, we accept the null hypothesis. This implies that the pretest and posttest performance of the group under study varies insignificantly.

Table 2. T-test of the Pretest and Posttest Performance

\begin{tabular}{lllllll}
\hline & $\mathrm{N}$ & Mean & $\mathrm{SD}$ & Mean Difference & $\mathrm{p}$ & Interpretation \\
\hline Pretest & 28 & 1.93 & 0.88 & 0.36 & 0.33 & Not significant \\
Posttest & 28 & 2.29 & 0.95 & & & \\
\hline
\end{tabular}

With the p value less than 0.05 between the pretest and posttest scores, interpreted as having no significant difference, further implies that using games in teaching the subject, though students liked and enjoyed it, it did not really help the students improve their understanding and learning the concepts.

This result is in consonance with the findings of Rachels' study where his research found no significant difference in students' Spanish achievement between those who were taught using games and those who were taught through traditional methods. ${ }^{\left({ }^{(8)}\right.}$

Though in the experiment of Laskowski "Gamification in Higher Education: A Case Study", produced promising results, authors did not find any correlation between attendance of higher class and received low grades by the group in the gamified class. ${ }^{(9)}$ 
But this result are in contrast with Bicen's Perceptions of Students for Gamification Approach: Kahoot as a Case Study" (10), Saran's Gamification in e-learning: The Effect on Student Performance ${ }^{(11)}$, Hong's study Effects of Gamification on Lower Secondary School ${ }^{(12)}$ where the adoption of a gamification strategy increased students' interest in the lesson and their desires for success, according to the data. The results showed that students in the experimental group had higher grades than students in the control group, demonstrating a statistically significant difference in post-test scores. This strategy was also discovered to be beneficial to student motivation. In addition, the findings of this study show that the Kahoot program may be utilized to successfully gamify courses.

Furthermore, while the results of the study by Çakıroğlu indicated that using games in the process of instruction, had a good impact on the students' statistical knowledge in middle and high-achieving students, the impact of gamification on lowachieving students was not beneficial. ${ }^{(13)}$

Similarly, the findings of Ekici's study show that incorporating game elements into a flipped classroom increases motivation, participation, and learning performance. However, there was insufficient evidence to generalize the findings. ${ }^{(14)}$

In the literature review of Manzano-León, a total of fourteen studies were reviewed. These were conducted using either the experimental design or the quasi-experimental design. The majority of them consider gamification to be an effective learning strategy. The findings were in consonance with the conclusion that gamification of education has the potential to improve students' commitment, motivation, and academic performance. ${ }^{(15)}$

\section{Conclusion and recommendations}

\section{Summary}

This study was done to find out the difference in the performance of the students under study in their pretest and posttest.

This study used the one group pretest - posttest experimental research design. It tried to find out the difference in the pretest and posttest performance of the single group under study.

The mean was used to determine the average mathematics performance of the subjects under study. T - test was used to find the difference in the pretest and posttest scores.

\section{Findings}

Based on the results, the following findings were formulated;

1. The mean of the pretest performance of the 28 -member single group under study understandably low at 1.93 , with a standard deviation of 0.88

2. The mean of the posttest performance at 2.29 with a standard deviation of 0.95 was higher than the pretest performance, implying that learning took place.

3. The t-test result between the pretest and posttest performance revealed a minimal mean difference which implies that the pretest and posttest performance of the group under study varies insignificantly.

4. The $\mathrm{p}$ value less than 0.05 between the pretest and posttest scores implied that using games in teaching the subject did not help the students improve their understanding the math concepts.

\section{Conclusions}

Based on the results, scores obtained in both the pretest and posttests were low, though there was an increase in the posttest performance, the mean score was still considerably low.

Based on statistics, there was no significant difference in the pretest and posttest performance of the group under study

Results of the study were limited to the concept of problem solving for non-routine mathematics word problems among BEED students of Eastern Samar State University. It also limits it result to a single class group of tertiary students.

\section{Recommendations}

Based on the findings, the following are recommended;

1. Before beginning the course, mathematics teachers should get to know their pupils so that they may choose and use the best teaching technique and method for them. Teachers should employ games not only in math classes to help students better understand concepts. 
2. Professors should be encouraged to employ alternative teaching methods that put students at the center of the teachinglearning process.

3. Educators and academics should be sent to seminars on new educational trends, tactics, and approaches by school administrators.

4. Future researchers may repeat this experiment to confirm the findings of this study.

\section{References}

1) Glover I. Play as you learn: gamification as a technique for motivating learners. In: Proceedings of World Conference on Educational Multimedia, Hypermedia and Telecommunications. 2013;p. 1-11. Available from: http://shura.shu.ac.uk/7172/.

2) Hanus MD, Fox J. Assessing the effects of gamification in the classroom: A longitudinal study on intrinsic motivation, social comparison, satisfaction, effort, and academic performance. Computers \& Education. 2015;80:152-161. Available from: https://dx.doi.org/10.1016/j.compedu.2014.08.019.

3) Arnold BJ. Gamification in Education. In: Annual American Society of Business and Behavioral Sciences (ASBBS) Conference. 2014.

4) Brull S, Finlayson S. Importance of Gamification in Increasing Learning. The Journal of Continuing Education in Nursing. 2016;47(8):372-375. Available from: https://dx.doi.org/10.3928/00220124-20160715-09.

5) Furdu I, Tomozei C, Kose U. Pros and Cons Gamification and Gaming in Classroom. BRAIN: Broad Research in Artificial Intelligence and Neuroscience. 2017;8:56-62. Available from: https://arxiv.org/abs/1708.09337.

6) ... Available from: https://www.ryerson.ca/content/dam/lt/resources/handouts/gamification.pdf.

7) Camarista G. The Art of Problem Solving. Lorimar Publishing. 2016. Available from: https://lorimaracademix/the-art-of-problem-solving/.

8) Rachels J, Richard. The Effect of Gamification on Elementary Students' Spanish Language Achievement and Academic Self-Efficacy. Lynchburg, VA. 2016. Available from: https://digitalcommons.liberty.edu/doctoral/1246/.

9) Laskowski M, Badurowicz M. Gamification in Higher Education: A Case Study. International Conference 971-975.

10) Bicen H, Kocakoyun S. Perceptions of Students for Gamification Approach: Kahoot as a Case Study. International Journal of Emerging Technologies in Learning. 2018;13(02):72-72. Available from: https://dx.doi.org/10.3991/ijet.v13i02.7467.

11) Saran M, Al-Magsoosi D, Mohammed D, Mohammed D. Gamification in e-learning: The Effect on Student Performance, Conference Paper. 2018. Available from: https://hdl.handle.net/20.500.12416/4270.

12) Hong G, Yung M, Masood. Effects of Gamification on Lower Secondary School Students' Motivation and Engagement. World Academy of Science, Engineering and Technology. 2014;8(12).

13) Çakıroğlu Ü, Güler M. Gamification in Higher Education: A Case Study. 2014;p. 971-975. Available from: https://www.semanticscholar.org/paper/ Gamification-in-Higher-Education\%3A-A-Case-Study-Laskowski-Badurowicz/b1bef95cd7aca248dccd1532dafc4db6e1a22229.

14) Ekici M. A systematic review of the use of gamification in flipped learning. Education and Information Technologies. 2021;6:1-20. Available from: https://www.researchgate.net/publication/348291127_A_systematic_review_of_the_use_of_gamification_in_flipped_learning.

15) Manzano-León A, Camacho-Lazarraga P, Guerrero MA, Guerrero-Puerta L, Aguilar-Parra JM, Trigueros R, et al. Between Level Up and Game Over: A Systematic Literature Review of Gamification in Education. Sustainability. 2021;13(4):2247-2247. Available from: https://dx.doi.org/10.3390/su13042247. 